\title{
Assessing the Impact of Including Traversal across Slope on Least Cost Path Accuracy: A Roman road case study
}

\begin{abstract}
Despite the methodological issues of Least Cost Path analysis being well known, the inclusion of traversal across slope has not been assessed. This paper uses a Roman road built along a ridge in Cumbria, England as a case study. The 'High Street' Roman road provides a suitable case study as its route along the ridge is dictated by the topography. By comparing the computed Least Cost Path results when including and not including traversal across slope as a cost component, this research has found that the inclusion results in Least Cost Paths that more accurately model the known route of the Roman road along the ridge. The Least Cost Path model when not including traversal across slope resulted in $84.8 \%$ of the Least Cost Path being within $600 \mathrm{~m}$ of the known route, compared to $100 \%$ when including traversal across slope. Due to the application of anisotropic cost functions, this research also identified that both Least Cost Path models predicted the route from the south towards the north frontiers more accurately, suggesting the Roman road was built with this direction of movement in mind.
\end{abstract}

\section{Introduction}

The movement of past peoples in the landscape has been studied extensively through the use of Geographic Information Systems (GIS) and Least Cost Path (LCP) analysis (Batten, 2007; Bell and Lock, 2000; Fiz and Orengo, 2008; Güimil-Fariña and Parcero-Oubiña, 2015; Howey, 2007; Kantner and Hobgood, 2003; Siart et al., 2008; Supernant, 2017; van Lanen et al., 2015; Verhagen et al., 2014; Verhagen and Jeneson, 2012). By using terrain in conjunction with other factors that may have influenced movement through a landscape, LCP models have been used to identify long-distance routes (e.g. Batten, 2007; Palmisano, 2017); to understand road networks (e.g. Bell et al., 2002; Fábrega Álvarez and Parcero Oubiña, 2007; Murrieta-Flores, 2012); and to assess factors that were taken into account during route construction (e.g. (Bell and Lock, 2000; Fonte et al., 2017; Kantner and Hobgood, 2003; Verhagen and Jeneson, 2012).

Despite the methodological issue of incorporating slope within the LCP modelling process being well known (e.g. Herzog, 2014a, 2014b), the impact of only including slope whilst ignoring the ability to traverse across slope has not been assessed (Bell and Lock, 2000; Conolly and Lake, 2006; Herzog, 2014b). By not incorporating traversal across within the LCP modelling process, the LCP model cannot accurately account for the difficulty when moving in all directions through a landscape (Bell and Lock, 2000; Conolly and Lake, 2006). More specifically, the greater ease in moving perpendicular to the aspect of slope is not included (Bell and Lock, 2000). This can affect the computed LCP and may result in incorrect assessments of past mobility patterns.

Using a Roman road built along a ridge in Cumbria, England as a case study, this paper assesses the impact of LCP accuracy when incorporating traversal across slope. Mobility along ridges and high up along the slope is associated with the Roman period (Bishop, 2014; Davies, 2002; Sherman and Evans, 2004; Verhagen et al., 2014; Wright, 1990, 12-13). Ridges are long-distance routes that extend across higher ground and form natural corridors for movement (Bradley, 2007; Llobera et al., 2004). The High Street Roman road in Cumbria is a suitable case study as its route along the ridge is dictated by the difficult topography of the High Fells (The Royal Commission on Historical Monuments of England, 1936). The leading hypothesis within this research is that the LCPs calculated with traversal across slope incorporated will more accurately predict the location of the Roman road compared to when traversal of slope is not incorporated. In order to test the hypothesis, this paper introduces the $\mathrm{R}$ package leastcostpath for the traversal across slope cost component and general LCP calculation (Lewis, J, 2019).

\section{Case study: The 'High Street' Roman road}

During the late first century AD and early second, forts north of the Tyne-Solway isthmus were abandoned (Breeze and Dobson, 1985). The forts of Brougham and Ambleside were subsequently built and occupied (Breeze, 1988) (Figure 1). The High Street Roman road (Figure 2), likely built during the late first or early second century A.D (Breeze and Dobson, 1985, 6; Hindle, 1998; Shotter, 2004, 53), is thought to have connected these two forts and provided connection to the main-western route to Carlisle (Codrington, 1919, 155-157; Cool, 2007, 55; Shepherd, 2004, 29). Although the origin of the High Street as a Roman road has been questioned (Collingwood, 1937, 1; Hindle, 1998, 16; Poulter, 2010, 66-67; The Royal Commission on Historical Monuments of England, 1936; Whitehead and Elsworth, 2008, 243). 


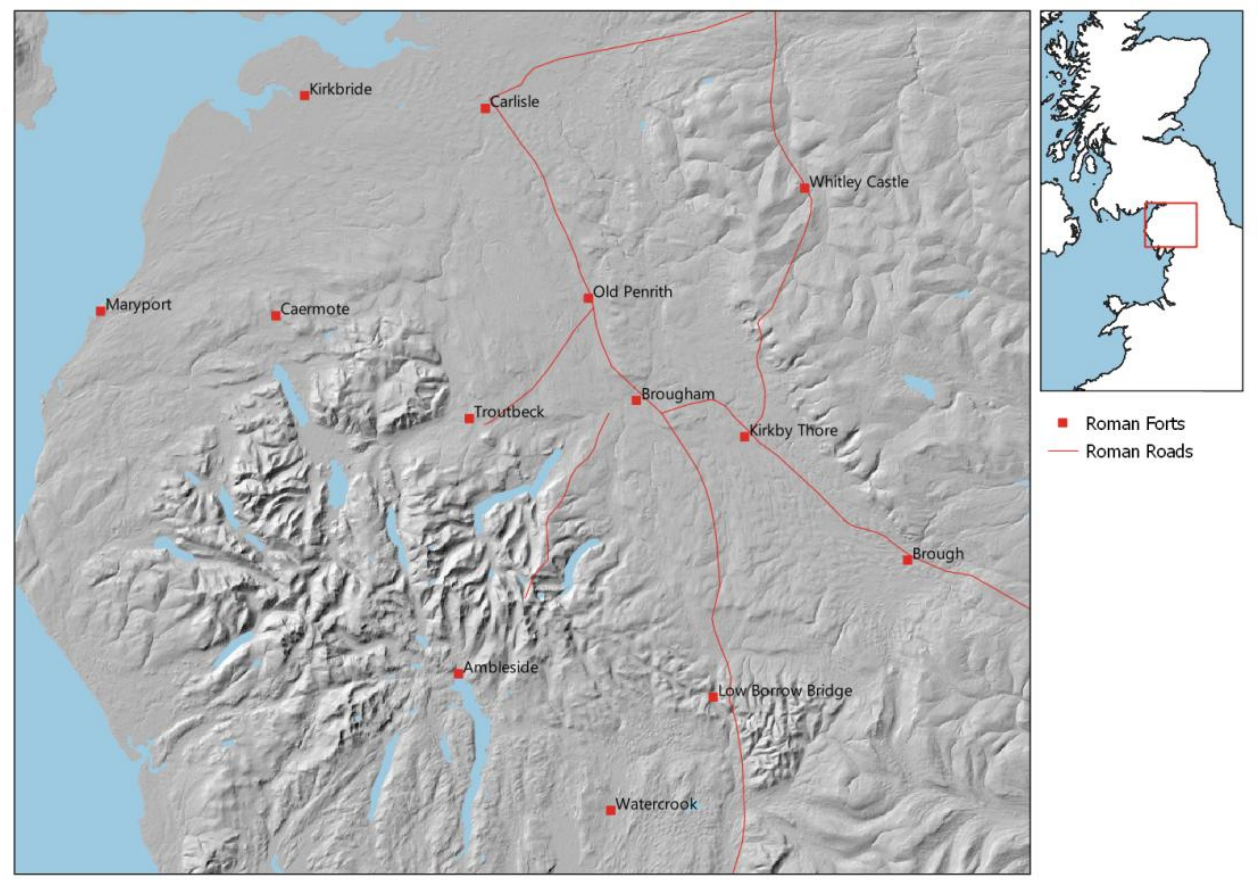

Figure 1. Military dispositions in North-West England in AD 95. Based on Breeze and Dobson $(1985,6)$
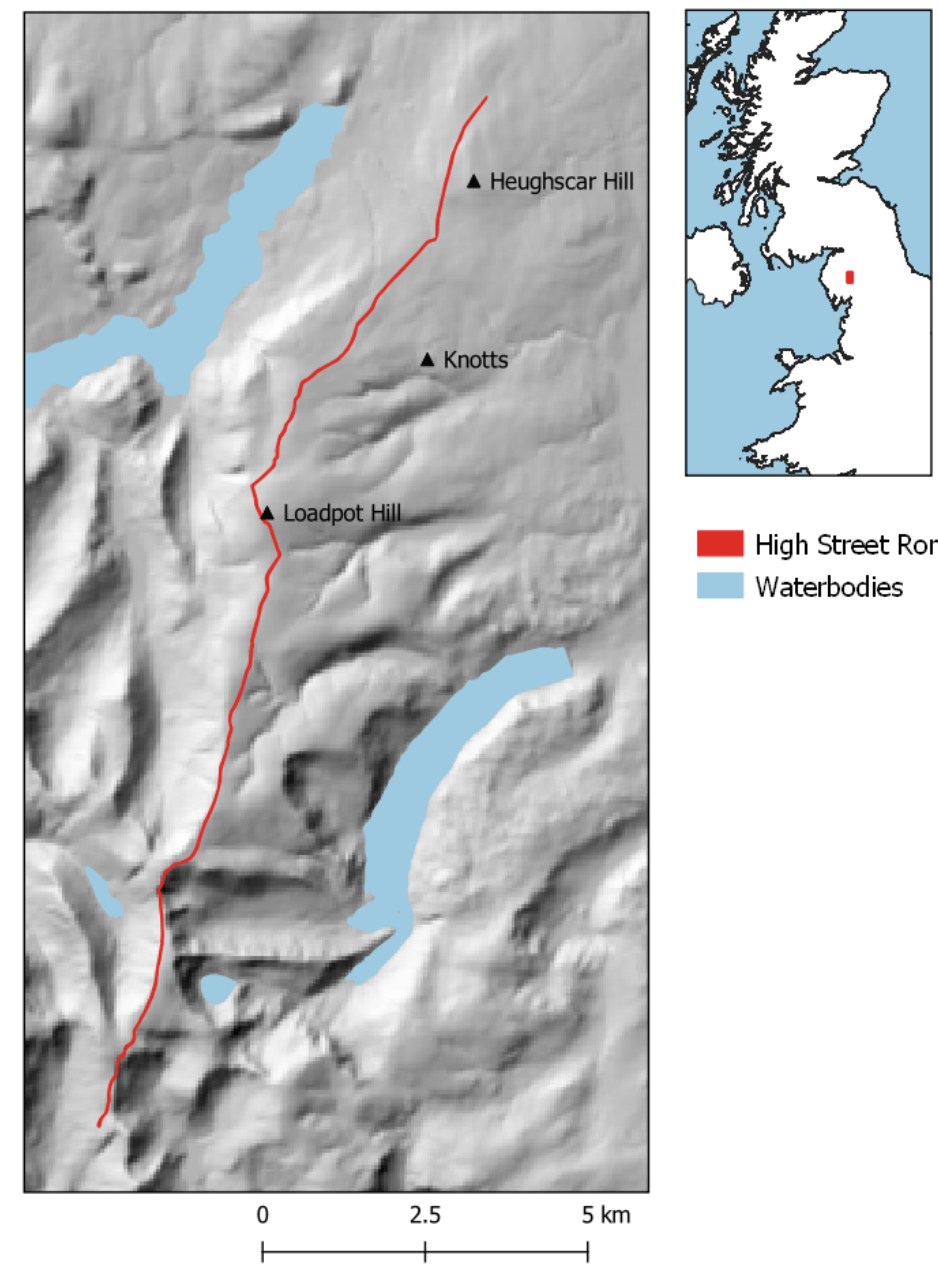

High Street Roman road

Waterbodies

Figure 2. High Street Roman road connecting the Roman forts of Brougham (North) and Ambleside (South) 


\section{Data and methods}

\subsection{High Street Roman road}

In order to validate the accuracy of the computed LCPs, the known route of the High Street Roman road is required. Despite being available from other sources (e.g. Bishop, 2014; Talbert and Bagnall, 2000), the extant route of the Roman road was recorded by Whitehead and Elsworth (2008) during an archaeological evaluation of the area. This represents the most accurate representation of the Roman road available, whilst also only including that which can be identified in the field (see (Collingwood, 1930, 118; Nicholson, 1861, 7 for discussion on the uncertainty around north and south section of the road). The location of the Roman road was retrieved from the Historic England Scheduled Monuments via https://historicengland.org.uk/listing/thelist/data-downloads/ (List Entry - 1003275).

\subsection{Waterbodies}

To ensure that travel across water is prohibited in the LCP computation, the Lake Waterbodies dataset provided by the Environment Agency was downloaded from https://data.gov.uk/dataset/da4a6c1f-7349-4d0e-9d218c90aa387b54/wfd-lake-waterbodies-cycle-2. The Lake Waterbodies identifies all bodies of standing inland surface water in England.

\subsection{LCP Analysis Overview}

When travelling in a landscape, humans will attempt to optimise the cost of travelling through choosing the path of least resistance (Surface-Evans and White, 2012; Wheatley and Gillings, 2002). LCP analysis identifies the path of least resistance by calculating the optimal connection between locations based on distance and the cost needed to cover the distance (Hardin et al., 2012; Verhagen and Jeneson, 2012). The cost of travelling in a landscape is often based on environmental factors such as slope (Surface-Evans and White, 2012), vegetation cover (Herzog, 2010; Surface-Evans and White, 2012), or visibility (Herzog, 2013; Rahn, 2005; Verhagen et al., 2014; Verhagen and Jeneson, 2012), however social factors have also been deemed important (Herzog, 2013; Murrieta-Flores, 2014; Surface-Evans and White, 2012).

Once the factors, also known as cost components (Herzog, 2014a), are identified, an appropriate cost function should be selected (Herzog, 2013). The cost function allows for the calculation of the cost of each move from a raster cell to its neighbour (Herzog, 2014a). From this, a final cost surface is created, which numerically expresses the difficulty of moving between individuals cells in a raster grid (White and Barber, 2012). The total cost value of each cell in the raster grid is accumulated by a spreading algorithm (Herzog, 2013), which assigns an accumulated cost value to each cell (Lee and Stucky, 1998). The accumulated cost values are then used to retrace the lowest values from the destination to the origin, resulting in the LCP (Herzog, 2014a).

\subsection{Software used to perform the LCP Analysis}

LCP analysis has been implemented in multiple GIS software such as ArcGIS and GRASS (Surface-Evans and White, 2012). Although frequently used for the modelling of past movement (Beyin et al., 2019; Gustas and Supernant, 2017; Kealy et al., 2018; Li et al., 2019; Verhagen and Jeneson, 2012), methodological issues are often ignored and can lead to the model not realistically representing the cost of movement through a landscape (Herzog, 2014a; Surface-Evans and White, 2012; Verhagen et al., 2019). Most notably, the spreading algorithm, which identifies the lowest cost from destination to origin, is implemented differently in different LCP software, resulting in LCP results that may not be comparable (Gietl et al., 2008; Herzog, 2013; Herzog and Posluschny, 2011). Similarly, the incorporation of isotropic cost functions assume that travel across a surface is the same regardless direction of movement (Taliaferro et al., 2010).

To overcome these methodological issues, the R package leastcostpath was used (Lewis, J, 2019). Leastcostpath is built using the classes and functions provided in the R package gdistance (van Etten, 2017). The R package gdistance allows up to 16 directions, which ensures that the elongation error is minimised, whilst not being computationally prohibitive (Herzog, 2014a), as well as allowing for greater flexibility in the calculation of cost surfaces than GIS software (van Etten, 2017). Furthermore gdistance allows for anisotropic cost functions by utilising matrices, a method proposed by Yu et al. (2003). Anisotropic cost functions are dependent on the direction of movement (Herzog, 2013), and enable the cost of travelling from origin to destination to be different from destination to origin resulting in LCPs that may predict different paths depending on the direction of movement (Herzog, 2010; Kantner, 2004). Although gdistance has previously been used in archaeological 
LCP research (e.g. (Slawisch and Wilkinson, 2018), the R package leastcostpath provides an easy-to-use, accessible platform for archaeological least cost path analysis, and mobility modelling more generally.

\subsection{Cost Components}

\subsubsection{Effective Slope}

In order to represent the real-world topography and to derive slope, a digital elevation model (DEM) was used. The SRTM digital elevation model of the study area was retrieved from https://dwtkns.com/srtm $30 \mathrm{~m} /$. The resolution of the DEM is 1 arc seconds (approximately 30m). Although the coarse resolution of the DEM can affect the accuracy of the LCP (Branting, 2012; Conolly and Lake, 2006; Herzog and Posluschny, 2011; Kantner, 2012; Wheatley and Gillings, 2002), limitations in computational power and access to data sources necessitated its use.

Nearly all archaeological LCP studies are based on slope as it is critical for all pedestrian travel (Herzog, 2014a, 2010; Howey, 2007). Slope is commonly calculated by recording the slope value of the direction of steepest descent (Herzog, 2014a). However, this does not reflect the anisotropic properties of slope, with the slope value being dependent on the direction of descent (Conolly and Lake, 2006; Herzog, 2014a). Effective slope, which takes into account the direction of descent, is implemented in gdistance by calculating the difference in elevation between cells and all of its neighbouring cells. A cost function, which calculates the difficulty of moving between cells in relation to the cost in terms of time or energy when walking, is applied to the slope values (Güimil-Fariña and Parcero-Oubiña, 2015; Herzog, 2010)

By applying the cost function to the effective slope, the direction of movement is taken into account and provides a more realistic representation of the cost of movement through a landscape (Surface-Evans and White, 2012.; Wheatley and Gillings, 2002). The most widely used anisotropic cost function in archaeological LCP analysis is the 'Hiking Function' (Tobler, 1993). This function assesses the time necessary to traverse a surface, whilst taking into account up-slope and down-slope momentum (Kantner, 2004). More recently, Márquez-Pérez et al. (2017) developed a 'Modified Hiking Function', which combines the continuity of Tobler's Hiking Function with the precision of MIDE, a method for calculating walking hours for an average hiker (París Roche, 2002). Márquez-Pérez et al.( 2017) reported an improvement over current cost functions, and has been shown to more accurately predict the location of Roman roads in Britain (Lewis, 2017). Therefore, the 'Modified Hiking Function' will be used in this research.

\subsubsection{Traversal across Slope}

Although applying a slope-based cost function to the anisotropic slope values calculates the cost when moving up-slope and down-slope, slope does not exert a force uniformly in all directions (Bell and Lock, 2000). 100\% of force is exerted when moving downhill, whilst there will be little impedance to movement when walking perpendicular to the slope (Bell and Lock, 2000). Therefore, by not incorporating traversal across slope, the calculated cost of movement through a landscape does not sufficiently model the difficulty when moving in all directions (Conolly and Lake, 2006). Bell and Lock (2000) proposed the 's-curve' as a method for calculating the difficulty of movement when moving perpendicular to the slope (Figure 3). For example, 45 degree uphill will exert $50 \%$ of force against the walker, whilst a 45 degree downhill will exert $50 \%$ of force with the walker. 


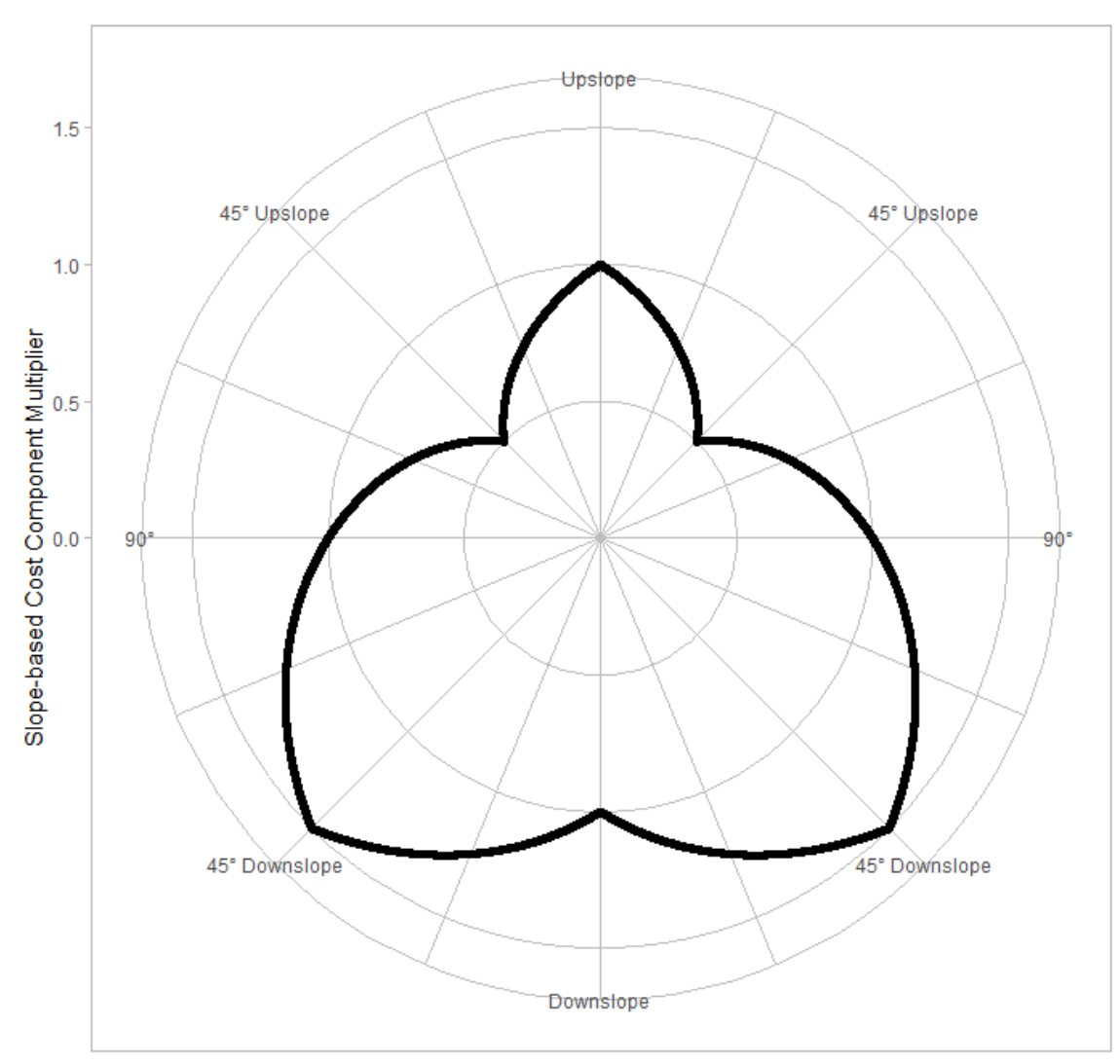

Figure 3. Traversal across slope cost function

The angle of movement across a slope is derived by calculating the angle perpendicular to the direction that the slope faces (i.e. aspect) for each raster cell. The difference in the angle of movement from each cell to its neighbouring cells is calculated. This value is then mapped to the traversal across slope cost function (Figure 3), resulting in the difficulty of traversing across slope.

\subsection{Validation of $L C P$ results}

The computed LCPs will be validated through the method proposed by Goodchild and Hunter (1997) when comparing two linear features. Already applied by Güimil-Fariña and Parcero-Oubiña (2015) in their study on Roman roads, the method calculates the percentage of the LCPs within set buffer distances from the known location of the High Street Roman road. Although subjective, the buffer distances used within this research are $150 \mathrm{~m}, 300 \mathrm{~m}, 450 \mathrm{~m}$, and $650 \mathrm{~m}$.

\subsection{Least Cost corridors}

Least cost corridors are used in this research to visually demonstrate how the inclusion of traversal across slope affects the cost associated with moving through the landscape.

By combining the accumulated cost surfaces from origin-to-destination and destination-to-origin, it is possible to create a combined least cost surface which takes into account both directions of movement (Gietl et al., 2008; Herzog, 2014a; Palmisano, 2017; Rademaker et al., 2012; Slawisch and Wilkinson, 2018). From this, areas of preferential movement can be identified by only selecting cells of the cost surface that have cost values below a set threshold (Surface-Evans, 2012).

The lowest 10 percent of cost was selected from both the traversal and non-traversal combined least cost surface. Although arbitrary, the lowest 10 percent was chosen as it successfully highlights the differences in the two models' areas of preferential movement.

\section{Results}

4.1 Overall accuracy of computed LCPs 
The results of the LCP analyses with slope and waterbodies as the only cost component (Figure 4) and with slope, waterbodies and traversing slope (Figure 5) are presented below. The model with only slope and waterbodies as cost components resulted in LCPs that took little account of the natural corridor of movement along the ridge. This is reflected in the decreased accuracy of the LCPs when compared to the known location of the High Street Roman road (Table 1). However, it should be noted that due to the anisotropy of the applied cost function the two LCPs predicted different paths, with the LCP from Ambleside to Brougham being more accurate than Brougham to Ambleside (84.8 and 54.6\% of LCP within 600m of known location of High Street Roman road, respectively).

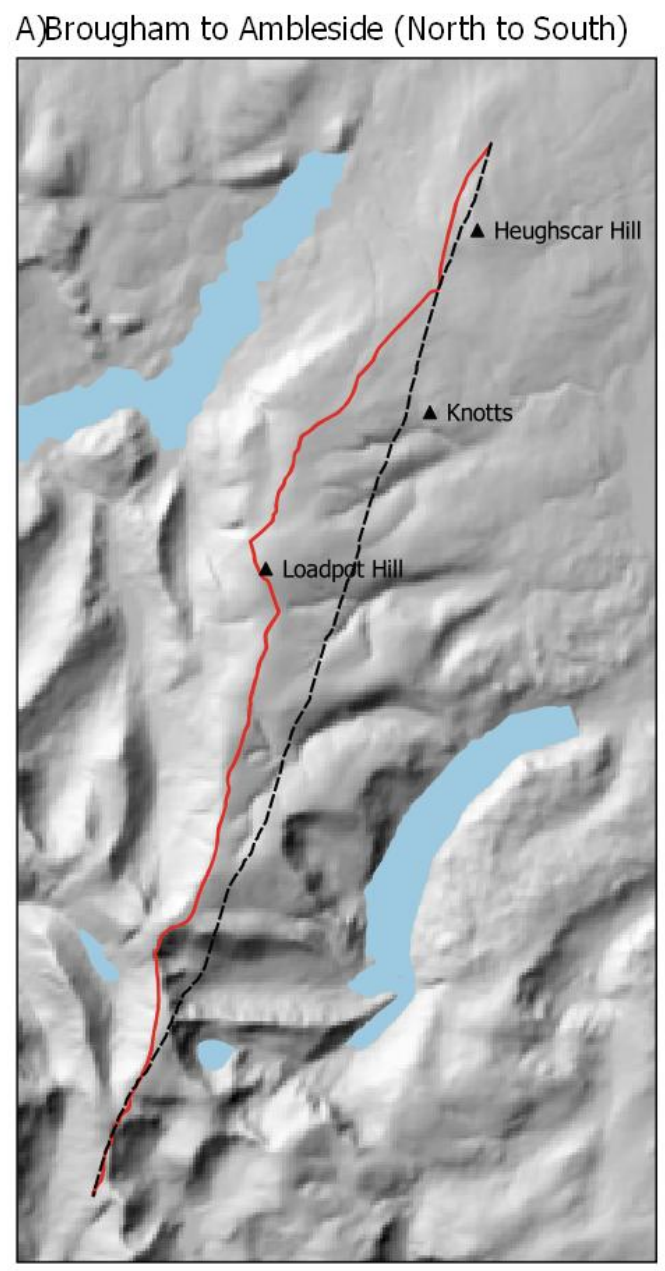

\section{B)Ambleside to Brougham (South to North)}
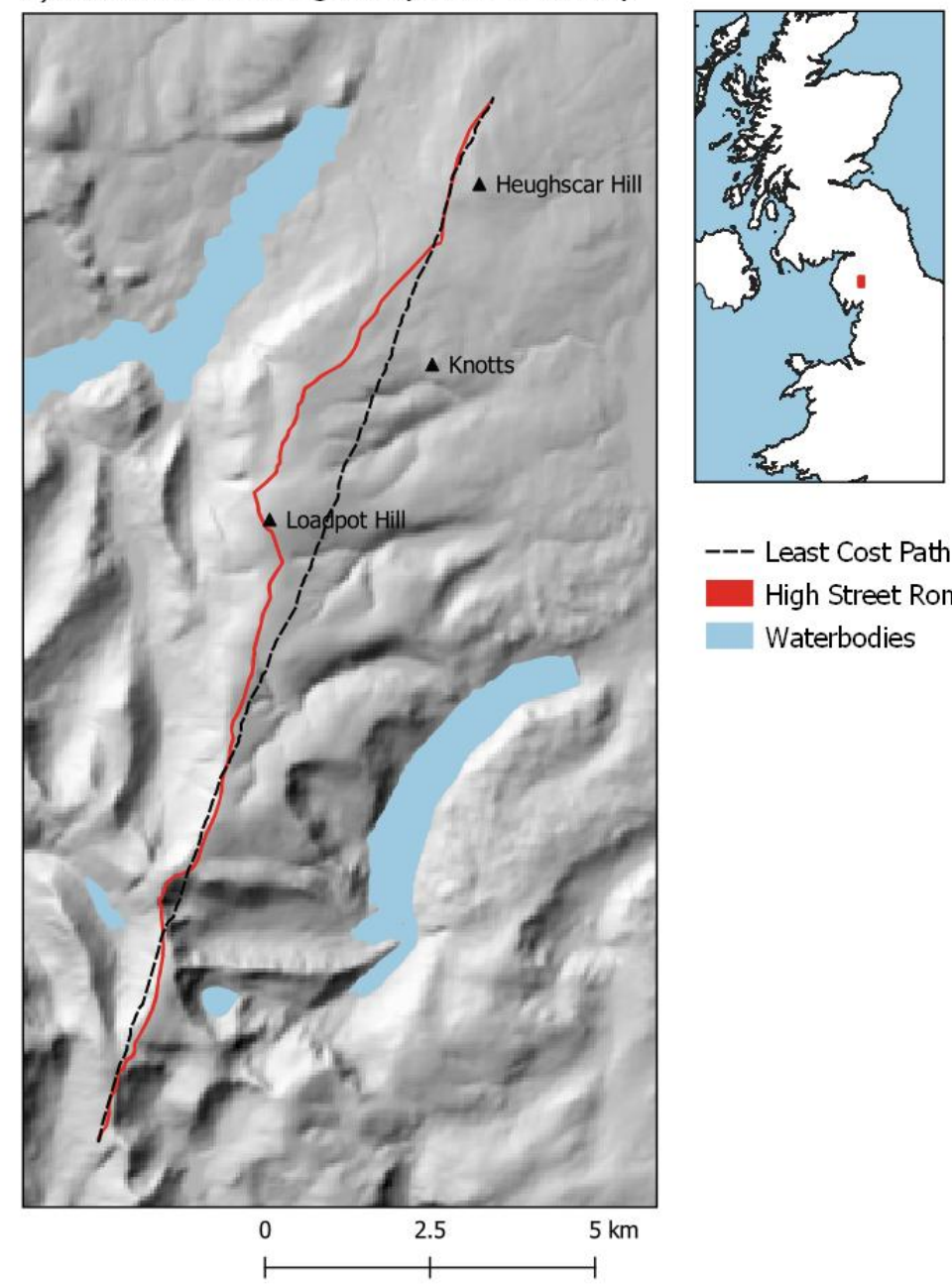

-- Least Cost Path

High Street Roman road Waterbodies

Figure 4. Computed Least Cost Paths using slope and Waterbodies as cost components

\begin{tabular}{|c|c|c|c|c|}
\hline Direction of LCP & $\begin{array}{c}\text { \% of LCP within } \\
\text { buffer (150m) }\end{array}$ & $\begin{array}{c}\text { \% of LCP within } \\
\text { buffer }(300 \mathrm{~m})\end{array}$ & $\begin{array}{c}\text { \% of LCP within } \\
\text { buffer (450m) }\end{array}$ & $\begin{array}{c}\text { \% of LCP within } \\
\text { buffer (600m) }\end{array}$ \\
\hline $\begin{array}{c}\text { Brougham to } \\
\text { Ambleside }\end{array}$ & 25.1 & 35.7 & 46.2 & 54.6 \\
\hline $\begin{array}{c}\text { Ambleside to } \\
\text { Brougham }\end{array}$ & 55.5 & 67.8 & 78.7 & 84.8 \\
\hline
\end{tabular}

Table 1. Least Cost Path accuracy using slope and Waterbodies only as cost components

In contrast, the LCPs when including traversal across slope produced paths that more closely resemble the known location of the High Street Roman road (Figure 5). Like the LCPs produced when only including slope and waterbodies as cost components, the LCP from Ambleside to Brougham is more accurate than the Brougham to Ambleside LCP (Table 2). 
A)Brougham to Ambleside (North to South)

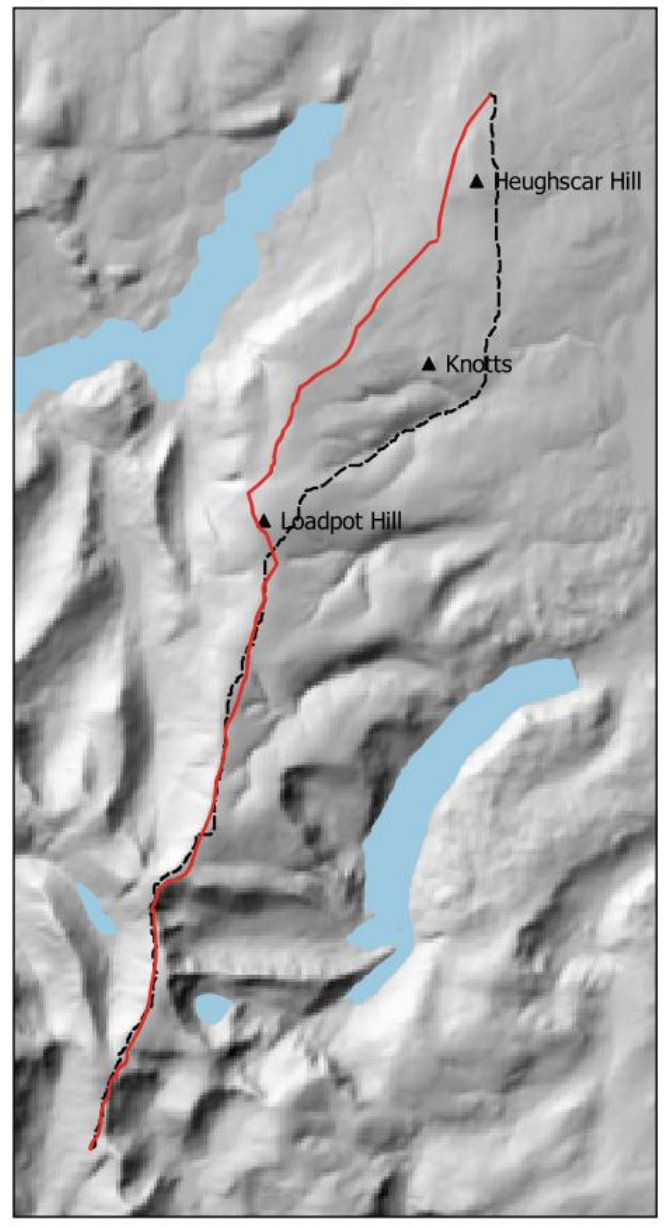

B)Ambleside to Brougham (South to North)

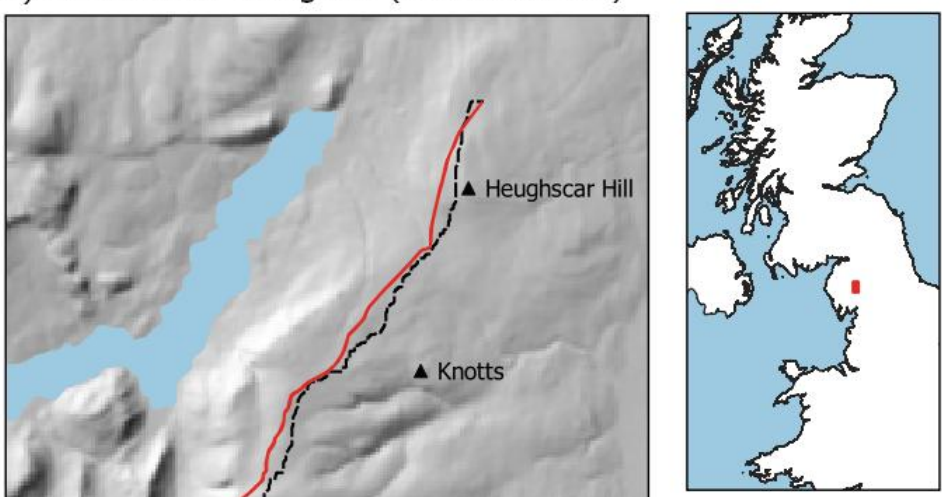

Least Cost Path

High Street Roman road Waterbodies

Figure 5. Least Cost Paths using slope, traversal across slope and Waterbodies as cost components

\begin{tabular}{|c|c|c|c|c|}
\hline Direction of LCP & $\begin{array}{c}\text { \% of LCP within } \\
\text { buffer }(150 \mathrm{~m})\end{array}$ & $\begin{array}{c}\text { \% of LCP within } \\
\text { buffer }(300 \mathrm{~m})\end{array}$ & $\begin{array}{c}\text { \% of LCP within } \\
\text { buffer }(450 \mathrm{~m})\end{array}$ & $\begin{array}{c}\text { \% of LCP within } \\
\text { buffer }(600 \mathrm{~m})\end{array}$ \\
\hline $\begin{array}{c}\text { Brougham to } \\
\text { Ambleside }\end{array}$ & 55.2 & 58.1 & 60.1 & 62.3 \\
\hline $\begin{array}{c}\text { Ambleside to } \\
\text { Brougham }\end{array}$ & 73.4 & 98.7 & 100.0 & 100.0 \\
\hline
\end{tabular}

Table 2. Least Cost Path accuracy using slope, traversal across slope and Waterbodies as cost components

\subsection{Least Cost corridors}

Figure 6 illustrates the difference in the area of preferential movement using the two LCP models. Unlike the LCP model using slope and Waterbodies as the only cost component, the lowest 10 percent of accumulated cost from the LCP model that includes traversal across slope can be seen to delineate the southern section of the known route of the Roman road, notably capturing the prominent bend in the road. 
A) Least Cost Corridor - Lowest $10 \%$

Traversal across slope not included

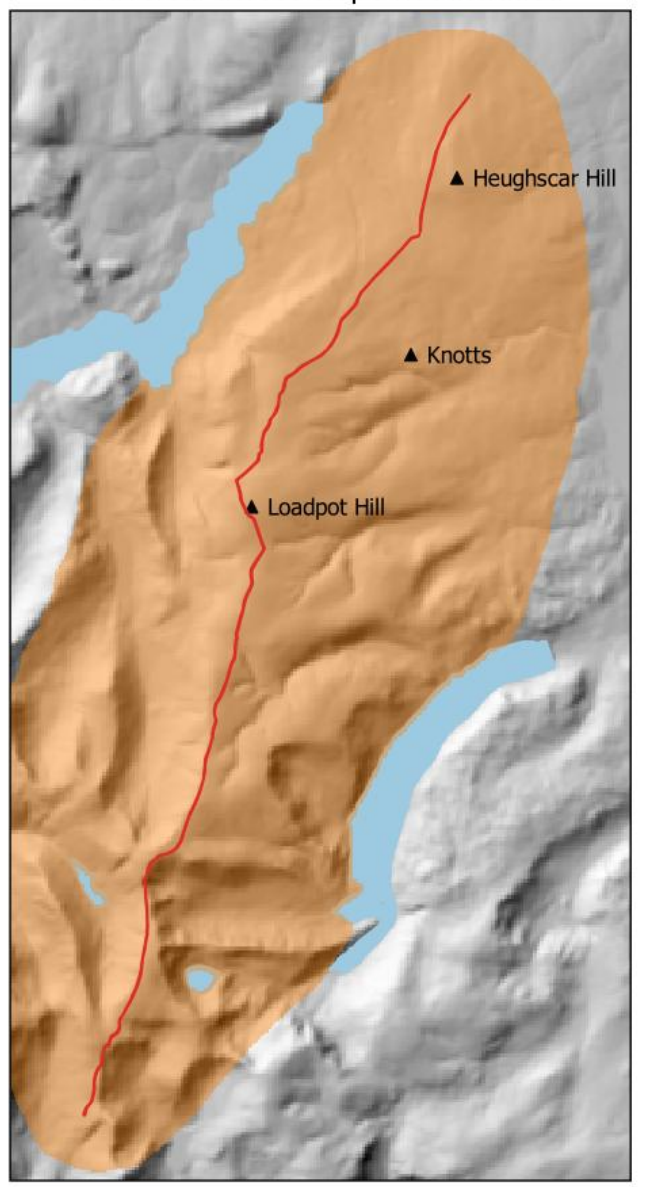

B) Least Cost Corridor - Lowest 10\%

Traversal across slope included

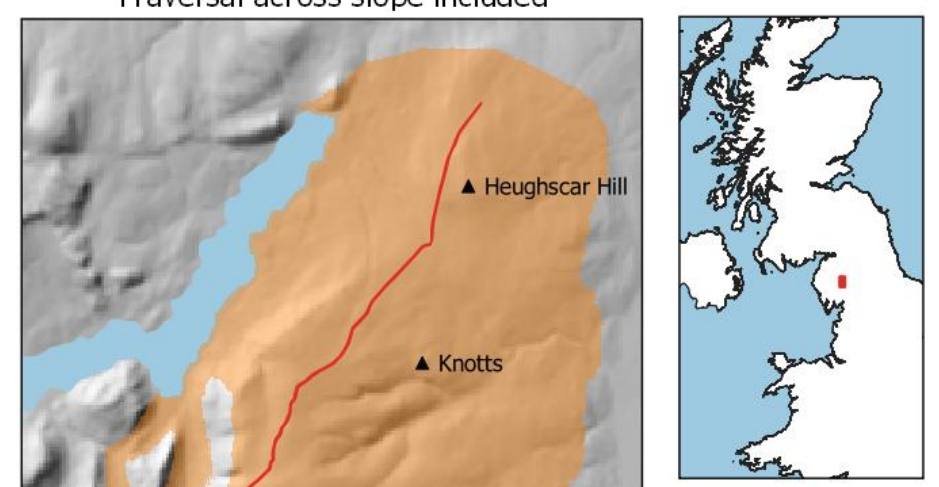

Least Cost Corridor - Lowest $10 \%$

High Street Roman road Waterbodies

Figure 6. Least Cost Corridors - lowest 10 percent of accumulated cost

\section{Discussion}

The findings have shown that the inclusion of traversal across slope as a cost component in the LCP calculation results in a more accurate prediction of the High Street Roman road in Cumbria. The inclusion of traversal across slope and the subsequent greater ease when moving across slope has resulted in the LCPs following the natural corridor of movement along the ridge, notably in the southern section of the study area. These findings support Bell and Lock's (2000) inclusion of traversal across slope when predicting the route of a prehistoric trackway in central England. Furthermore, this research suggests that traversal across slope as a cost component should be accounted for when least cost path analysis is conducted in mountainous topography with areas of higher ground that form natural corridors of movement.

Although this research did not aim to understand which direction the High Street Roman road was used, the application of anisotropic cost functions in the LCP calculation resulted in two LCPs following different routes. Notably, both LCP models predicted the route from Ambleside (south) to Brougham (north) more accurately and suggest that the Roman road was built with this direction of movement in mind. These results further strengthen the proposal that the High Street Roman road was built for movement of the army towards Carlisle and the northern frontier (Salway, 2009, p.135-136). This research has shown that the application of anisotropic cost functions in the LCP calculation can be useful in understanding the preferred direction of movement and should therefore be default when conducting LCP analysis.

Lastly, this research has demonstrated the benefits of open-source software and algorithms through the use of gdistance and leastcostpath. By using open-source rather than proprietary software, the analytical approach is more transparent and open for future reproducibility. Furthermore, the R package leastcostpath 
provides archaeologically bespoke functions such as traversal across slope, as well as overcoming common methodological issues when conducting least cost path analyses.

Despite this research showing that the incorporation of traversal across slope as a cost component results in a more accurate prediction of the High Street Roman road, the uncertainty in the digital elevation model and the propagation of error and how it may affect LCP results was not assessed. To increase confidence, as well as statistical validity, in the results presented, further research should be done where the uncertainty introduced during each step of the LCP modelling process is accounted for. Furthermore, this study should be replicated using a higher resolution DEM that better represents the topography of the study area.

\section{Conclusions}

Overall, this paper has shown that incorporation of traversal across slope as a cost component in the LCP analysis results in a more accurate prediction of the High Street Roman road. This research also demonstrates the potential value of using anisotropic cost functions within the LCP analysis to better understand the preferred direction of movement along routes. Furthermore, the use of the open-source $\mathrm{R}$ package gdistance and leastcostpath provides a LCP framework that is more transparent and open for future reproducibility. The uncertainty in the digital elevation model and the propagation of error and how it may affect LCP results has not been assessed and therefore further research is needed to determine the statistical validity of these results.

\section{References}

Batten, D. C. (2007). Least-cost pathways, exchange routes, and settlement patterns in Late Prehistoric East-Central New Mexico. In Computer Applications and Quantitative Methods in Archaeology, J. T. Clark, \& E. M. Hagemeister (Eds.), Digital discovery: exploring new frontiers in human heritage: CAA 2006 : computer applications and quantitative methods in archaeology (pp. 151-158). Budapest: Archaeolingua.

Bell, T, \& Lock, G. R. (2000). Topographic and cultural influences on walking the Ridgeway in later prehistoric times. In G. R. Lock, (Ed.), Beyond the map: archaeology and spatial technologies (pp. 85-100). Amsterdam; Washington, DC : Tokyo: IOS Press; Ohmsha [distributor].

Bell, Tyler, Wilson, A., \& Wickham, A. (2002). Tracking the Samnites: Landscape and Communications Routes in the Sangro Valley, Italy. American Journal of Archaeology, 106(2), 169-186. https://doi.org/10.2307/4126242

Beyin, A., Hall, J., \& Day, C. A. (2019). A Least Cost Path Model for hominin dispersal routes out of the East African Rift region (Ethiopia) into the Levant. Journal of Archaeological Science: Reports, 23, 763-772. https://doi.org/10.1016/j.jasrep.2018.11.024

Bishop, M. C. (2014). The secret history of the Roman roads of Britain. Barnsley, South Yorkshire: Pen \& Sword Military.

Bradley, R. (2007). The prehistory of Britain and Ireland. Cambridge ; New York: Cambridge University Press.

Branting, S. (2012). Seven Solutions for Seven Problems with Least Cost Pathways. In D. A. White \& S. L. SurfaceEvans (Eds.), Least Cost Analysis of Social Landscapes: Archaeological Case Studies. (pp. 209-224). Salt Lake City: University of Utah Press. http://qut.eblib.com.au/patron/FullRecord.aspx?p=3443847. Accessed 22 December 2019

Breeze, David J., \& Dobson, B. (1985). Roman Military Deployment in North England. Britannia, $16,1$. https://doi.org/10.2307/526389

Breeze, D.J. (1988). The Roman Army in Cumbria. Transactions of the Cumberland \& Westmorland Antiquarian \& Archaeological Society, 88, 9-22.

Codrington, T. (1919). Roman roads in Britain (3rd ed.). London: Society for Promoting Christian Knowledge.

Collingwood, R. G. (1930). Five Notes: The Southern End of High Street. Transactions of the Cumberland and Westmorland Antiqurian and Archaeological Society, 118.

Collingwood, R. G. (1937). Two Roman Mountain-Roads. Transactions of the Cumberland and Westmorland Antiqurian and Archaeological Society, 37, 1-12. 
Conolly, J., \& Lake, M. (2006). Geographical information systems in archaeology.

Cool, H. E. M. (2007). Telling stories about Brougham, or the importance of the specialist report. In R. Hingley, S. Willis, \& University of Durham (Eds.), Roman finds: context and theory: proceedings of a conference held at the University of Durham (pp. 54-58). Oxford: Oakville, CT: Oxbow; Distributed in the USA by David Brown.

Davies, H. (2002). Roads in Roman Britain. Stroud, Gloucestershire ; Charleston, SC: Tempus Pub.

Fábrega Álvarez, P., \& Parcero Oubiña, C. (2007). Proposals for an archaeological analysis of pathways and movement. Archeologia e Calcolatori (XVIII), 121-140.

Fiz, I., \& Orengo, H. A. (2008). Simulating Communication Routes in Mediterranean Alluvial Plains. In . Proceedings of the 35th International Conference on Computer Applications and Quantitative Methods in Archaeology (CAA), Berlin, Germany, April 2-6, 2007 (pp. 309-315). Presented at the Layers of Perception.

Fonte, J., Parcero-Oubiña, C., \& Costa-García, J. M. (2017). A Gis-Based Analysis Of The Rationale Behind Roman Roads. The Case Of The So-Called Via Xvii (Nw Iberian Peninsula). https://doi.org/10.5281/ZENODO.1005562

Gietl, R., Doneus, M., \& Fera, M. (2008). Cost Distance Analysis in an Alpine Environment: Comparison of Different Cost Surface Modules. In Proceedings of the 35th International Conference on Computer Applications and Quantitative Methods in Archaeology (CAA). Presented at the Layers of Perception, Berlin, Germany.

Goodchild, M. F., \& Hunter, G. J. (1997). A simple positional accuracy measure for linear features. International Journal of Geographical Information Science, 11(3), 299-306. https://doi.org/10.1080/136588197242419

Güimil-Fariña, A., \& Parcero-Oubiña, C. (2015). "Dotting the joins": a non-reconstructive use of Least Cost Paths to approach ancient roads. The case of the Roman roads in the NW Iberian Peninsula. Journal of Archaeological Science, 54, 31-44. https://doi.org/10.1016/j.jas.2014.11.030

Gustas, R., \& Supernant, K. (2017). Least cost path analysis of early maritime movement on the Pacific Northwest Coast. Journal of Archaeological Science, 78, 40-56. https://doi.org/10.1016/j.jas.2016.11.006

Hardin, E. M., Kurum, O., Mitasova, H., \& Overton, M. F. (2012). Least Cost Path Extraction of Topographic Features for Storm Impact Scale Mapping. Journal of Coastal Research, 28(4), 970-978. https://doi.org/10.2112/JCOASTRES-D-11-00126.1

Haverfield, F. (1899). Report of the Cumberland Excavation Committee for 1898. Cumberland and Westmorland Antiquarian and Archaeological Society Transactions, 15, 345-364.

Herzog, I. (2010). Theory and practice of cost functions. In Fusion of Cultures: Abstracts of the XXXVIII Conference on Computer Applications and Quantitative Methods in Archaeology (pp. 431-434). Granada: CAA 2010.

Herzog, I. (2013). The potential and limits of Optimal Path Analysis. In A. Bevan \& M. Lake (Eds.), Computational approaches to archaeological spaces (pp. 179-211). Walnut Creek, California: Left Coast Press.

Herzog, I, \& Posluschny, A. (2011). Tilt - slope-dependent least cost path calculations revisited. In E. Jerem, F. Redö, \& V. Szevérenyi (Eds.), On the road to reconstructing the past: Computer Applications and Quantitative Methods in Archaeology (CAA): proceedings of the 36th International Conference, Budapest, April 2-6, 2008 (pp. 212-218). Budapest: Archaeolingua. http://proceedings.caaconference.org/paper/cd31_herzog_posluschny_caa2008/. Accessed 22 December 2019

Herzog, I, \& Yépez, A. (2014). Analyzing Patterns of Movement and of Settlement in the East-Andean Mountains of Ecuador. Presented at the Conference on Cultural Heritage and New Technologies. November 8-10. Vienna, Austria. https://www.chnt.at/wp-content/uploads/eBook_CHNT19_Herzog_Yepez.pdf. Accessed 22 December 2019

Herzog, Irmela. (2014a). A Review of Least Cost Analysis of Social Landscapes. Archaeological Case Studies [Book]. Internet Archaeology, (34). https://doi.org/10.11141/ia.34.7

Herzog, Irmela. (2014b). Least-cost Paths - Some Methodological Issues. Internet Archaeology, (36). https://doi.org/10.11141/ia.36.5 
Hindle, B. P. (1998). Roads and tracks of the Lake District (Rev. ed.). Milnthorpe: Cicerone.

Howey, M. C. L. (2007). Using multi-criteria cost surface analysis to explore past regional landscapes: a case study of ritual activity and social interaction in Michigan, AD 1200-1600. Journal of Archaeological Science, 34(11), 1830-1846. https://doi.org/10.1016/j.jas.2007.01.002

Kantner, J. (2004). Geographical Approaches for Reconstructing Past Human Behaviour from Prehistoric Roadways. In M.F Goodchild \& D. G. Janelle (Eds.), Spatially Integrated Social Science: Examples in Best Practice (pp. 323-244). Oxford: Oxford University Press.

Kantner, J. (2012). Realism, Reality, and Routes: Evaluating Cost-Surface and Cost-Path Algorithms. In D. A. White \& S. L. Surface-Evans (Eds.), Least Cost Analysis of Social Landscapes: Archaeological Case Studies. (pp. 225-238). Salt Lake City: University of Utah Press. http://qut.eblib.com.au/patron/FullRecord.aspx?p=3443847. Accessed 22 December 2019

Kantner, J., \& Hobgood, R. (2003). Digital technologies and prehistoric landscapes in the American Southwest. In M. Forte \& P. R. Williams (Eds.), The reconstruction of archaeological landscapes through digital technologies: proceedings of the 1st Italy-United States workshop, Boston, Massachusetts, USA, November 1-3, 2001 (pp. 117-124). Oxford, England: Archaeopress.

Kealy, S., Louys, J., \& O'Connor, S. (2018). Least-cost pathway models indicate northern human dispersal from Sunda to Sahul. Journal of Human Evolution, 125, 59-70. https://doi.org/10.1016/j.jhevol.2018.10.003

Lee, D., \& Stucky, J. (1998). On applying viewshed analysis for determining least-cost paths on Digital Elevation Models. International Journal of Geographical Information Science, 12(8), 891-905. https://doi.org/10.1080/136588198241554

Lewis, J. (2019). leastcostpath: R Implementation of Least Cost Path Analysis (version 0.1.6). https://github.com/josephlewis/leastcostpath. Accessed 22 December 209AD

Li, F., Vanwezer, N., Boivin, N., Gao, X., Ott, F., Petraglia, M., \& Roberts, P. (2019). Heading north: Late Pleistocene environments and human dispersals in central and eastern Asia. PLOS ONE, 14(5), e0216433. https://doi.org/10.1371/journal.pone.0216433

Llobera, M., Wheatley, D. W., Steele, T. J. M., Cox, S., \& Parchment, O. (2004). Calculating the inherent visual structure of a landscape ('total viewshed') using high-throughput computing. In XXXII International Conference - Computer Applications in Archaeology 2004 - Computer Applications and Quantitative Methods in Archaeology, Beyond the Artifact: Digital Interpretation of the Past (17/04/04). https://eprints.soton.ac.uk/43036/

Márquez-Pérez, J., Vallejo-Villalta, I., \& Álvarez-Francoso, J. I. (2017). Estimated travel time for walking trails in natural areas. Geografisk Tidsskrift-Danish Journal of Geography, 117(1), 53-62. https://doi.org/10.1080/00167223.2017.1316212

Murrieta-Flores, P. (2012). Understanding human movement through spatial technologies. The role of natural areas of transit in the Late Prehistory of South-western Iberia. Trabajos de Prehistoria, 69(1), 103-122. https://doi.org/10.3989/tp.2012.12082

Murrieta-Flores, P. (2014). Developing computational approaches for the study of movement: assessing the role of visibility and landscape markers in terrestrial navigation during Iberian Late Prehistory. In S. Polla \& P. Verhagen (Eds.), Computational Approaches to the Study of Movement in Archaeology. Berlin, Boston: DE GRUYTER. https://doi.org/10.1515/9783110288384.99

Nicholson, C. (1861). The annals of Kendal: being a historical and descriptive account of Kendal and the neighbourhood: with biographical sketches of many eminent personages connected with the town. London/Kendal: Whitaker \& Co. https://archive.org/details/annalsofkendalbe00nich/. Accessed 22 December 2019

Palmisano, A. (2017). Drawing Pathways from the Past: the Trade Routes of the Old Assyrian Caravans Across Upper Mesopotamia and Central Anatolia. In F. Kulakoğlu, G. Barjamovic, \& K. R. Veenhof (Eds.), Movement, resources, interaction: proceedings of the 2nd Kültepe International Meeting, Kültepe, 26-30 July 2015: studies dedicated to Klaas Veenhof (pp. 29-48). Turnhout, Belgium: Brepols. 
Paris Roche, A. (2002). Método de Información para Excursiones (MIDE).

Poulter, J. S. (2010). The planning of Roman roads and walls in northern Britain. Stroud: Amberley. http://www.vlebooks.com/vleweb/product/openreader?id=none\&isbn=9781445612096. Accessed 22 December 2019

Rahn, B. (2005). Cost Surface-Derived Least-Cost Paths: A Case Study from Iron Age Orkney. Internet Archaeology, (19). https://doi.org/10.11141/ia.19.2

Salway, P. (2009). The frontier people of Roman Britain. Cambridge: Cambridge University Press.

Shepherd, M. (2004). From Hellgill to Bridge End: aspects of economic and social change in the Upper Eden Valley, 1840 - 95. Hatfield: Univ. of Hertfordshire Press.

Sherman, A., \& Evans, E. (2004). Roman Roads in Southeast Wales. Desk-Based Assessment with Recommendations for Fieldwork (No. 073). The Glamorgan-Gwent Archaeological Trust Ltd, Swansea. http://www.ggat.org.uk/cadw/cadw_reports/pdfs/GGAT\%2075\%20Yr3\%20Roads\%20final.pdf. Accessed 22 December 2019

Shotter, D. C. A. (2004). Romans and Britons in north-west England (New and rev. ed.). Lancaster: Centre for NorthWest Regional Studies, University of Lancaster.

Siart, C., Eitel, B., \& Panagiotopoulos, D. (2008). Investigation of past archaeological landscapes using remote sensing and GIS: a multi-method case study from Mount Ida, Crete. Journal of Archaeological Science, 35(11), 2918-2926. https://doi.org/10.1016/i.jas.2008.06.006

Slawisch, A., \& Wilkinson, T. C. (2018). Processions, Propaganda, and Pixels: Reconstructing the Sacred Way Between Miletos and Didyma. American Journal of Archaeology, 122(1), 101. https://doi.org/10.3764/aja.122.1.0101

Supernant, K. (2017). Modeling Métis mobility? Evaluating least cost paths and indigenous landscapes in the Canadian west. Journal of Archaeological Science, 84, 63-73. https://doi.org/10.1016/j.jas.2017.05.006

Surface-Evans, S. L. (2012). Cost Catchments. In D. A. White \& S. L. Surface-Evans (Eds.), Least Cost Analysis of Social Landscapes: Archaeological Case Studies. (pp. 128-151). Salt Lake City: University of Utah Press. http://qut.eblib.com.au/patron/FullRecord.aspx?p=3443847. Accessed 22 December 2019

Surface-Evans, S. L., \& White, D., A. (2012). An Introduction to Least Cost Analysis of Social Landscapes. In D. A. White \& S. L. Surface-Evans (Eds.), Least Cost Analysis of Social Landscapes: Archaeological Case Studies. (pp. 1-10). Salt Lake City: University of Utah Press. http://qut.eblib.com.au/patron/FullRecord.aspx?p=3443847. Accessed 22 December 2019

Talbert, R. J. A., \& Bagnall, R. S. (2000). Barrington atlas of the Greek and Roman world. Princeton, N.J: Princeton University Press.

Taliaferro, M. S., Schriever, B. A., \& Shackley, M. S. (2010). Obsidian procurement, least cost path analysis, and social interaction in the Mimbres area of southwestern New Mexico. Journal of Archaeological Science, 37(3), 536-548. https://doi.org/10.1016/j.jas.2009.10.018

The Royal Commission on Historical Monuments of England. (1936). Prehistoric and Roman Westmorland. In An Inventory of the Historical Monuments in Westmorland (pp. xxviii-xlvii). London: His Majesty's Stationery Office. https://www.british-history.ac.uk/rchme/westm/xxviii-xlvii. Accessed 22 December 2019

Tobler, W. (1993). Three Presentations on Geographical Analysis and Modeling (No. 93-1), Technical Report.

van Etten, J. (2017). R Package gdistance : Distances and Routes on Geographical Grids. Journal of Statistical Software, 76(13). https://doi.org/10.18637/jss.v076.i13

van Lanen, R. J., Kosian, M. C., Groenewoudt, B. J., Spek, T., \& Jansma, E. (2015). Best travel options: Modelling Roman and early-medieval routes in the Netherlands using a multi-proxy approach. Journal of Archaeological Science: Reports, 3, 144-159. https://doi.org/10.1016/j.jasrep.2015.05.024 
Verhagen, P, \& Jeneson, K. (2012). A Roman Puzzle: Trying to find the Via Belgica with GIS. In A. Chrysanthi, P. Murrieta-Flores, C. Papadopoulos, \& J. Huggett (Eds.), Thinking beyond the tool: archaeological computing and the interpretive process (pp. 123-130). Oxford: Archaeopress.

Verhagen, P, Polla, S., \& Frommer, I. (2014). Finding Byzantine junctions with Steiner trees. In S. Polla \& P. Verhagen (Eds.), Computational approaches to the study of movement in archaeology: theory, practice and interpretation of factors and effects of long term landscape formation and transformation (pp. 73-98). Berlin ; Boston: De Gruyter.

Verhagen, Philip, Nuninger, L., \& Groenhuijzen, M. R. (2019). Modelling of Pathways and Movement Networks in Archaeology: An Overview of Current Approaches. In Philip Verhagen, J. Joyce, \& M. R. Groenhuijzen (Eds.), Finding the Limits of the Limes (pp. 217-249). Cham: Springer International Publishing. https://doi.org/10.1007/978-3-030-04576-0_11

Wheatley, D., \& Gillings, M. (2002). Spatial technology and archaeology: the archaeological applications of GIS. New York: Taylor \& Francis.

White, D. A., \& Barber, S. B. (2012). Geospatial modeling of pedestrian transportation networks: a case study from precolumbian Oaxaca, Mexico. Journal of Archaeological Science, 39(8), 2684-2696. https://doi.org/10.1016/j.jas.2012.04.017

Whitehead, S., \& Elsworth, D. W. (2008). Investigation of part of the High Street Roman Road in Kentmer. Transactions of the Cumberland and Westmorland Antiqurian and Archaeological Society, 8, 241-246.

Wright, G. N. (1990). Roads and trackways of the Yorkshire Dales. Ashbourne: Moorland.

Yu, C., Lee, J., \& Munro-Stasiuk, M. J. (2003). Research Article: Extensions to least-cost path algorithms for roadway planning. International Journal of Geographical Information Science, 17(4), 361-376. https://doi.org/10.1080/1365881031000072645 